\title{
QUALITATIVE CHARACTERISTICS OF SAUSAGES MADE WITH ADDITION OF PUMPKIN AND BLACK SEED OILS
}

\author{
Boban Malinov', Aco Kuzelov² \\ ${ }^{1}$ MSc Student, Department of Food Technology and Processing of Animal products. \\ Faculty of Agriculture, Goce Delcev University - Stip, Krste Misirkov 10 - A, 2000 Stip, \\ Republic of North Macedonia \\ ${ }^{2}$ Department of Food Technology and Processing of Animal products. \\ Faculty of Agriculture, Goce Delchev University - Stip, Krste Misirkov 10 - A, 2000 Stip, \\ Republic of North Macedonia \\ *Corresponding author: bobanmalinov@yahoo.com
}

\begin{abstract}
This paper presents the results obtained from the examination on the impact of cold-pressed pumpkin oil and cold -pressed black seed oil on the chemical composition and oxidative changes (degree of acidity and peroxide value) of Bacon Folk sausages. The chemical composition of the groups of sausages was examined on the first and on the sixtieth day of production, and the degree of acidity and peroxide value were examined on $1^{\text {st }}, 10^{\text {th }}, 20^{\text {th }}, 35^{\text {th }}, 45^{\text {th }}$ and $60^{\text {th }}$ day of production. From the results it can be seen no statistically significant difference between the chemical compositions of the Bacon Folk Sausages produced by applying cold pressed pumpkin and black seed oils in terms of protein and mineral content. There is a greater variation in the fat content in groups (III, IV) produced with the addition of cold pressed pumpkin oil and black seeds. The acidity level is lower in the groups of sausages produced with cold pressed black seed oil. As the maturation increases in days, the acid level in all groups and all types of cold pressed oils also increases. On the first day of production in the groups of sausages produced with cold pressed black seed oil, the lowest peroxide number was found. On the sixtieth day of production we have the lowest peroxide number in the first group of cold pressed pumpkin oil.
\end{abstract}

Keywords: chemical composition, oxidative changes, sausage

\section{INTRODUCTION}

In recent years, the production and dietary use of cold-pressed vegetable oils has increased significantly. The most important factor in their quality is the raw material, which is procured from various domestic and imported sources. From this aspect, the purity and maturity of the seeds are important and they have a direct impact on the heat production quality of the cold-pressed oils (Qian Ying et al, 2018). The oils produced by this technology are rich in bioactive compounds, (Obiedzińska et al. ,2012). Various seeds and nuts are used as sources for the production of these oils (olive fruit, beet seed, flax, pumpkin, sunflower, sesame, primrose, pumpkin, black currant, black seed, walnuts). They are also consumed by people as healthy food. They are all rich sources of unsaturated fatty acids including essential fatty acids, bioactive compounds such as tocopherols and tocotrienols, free and esterified sterols, hydrocarbons (squalene), triterpene alcohols, carotenoids, chlorophylls and other compounds, which are extremely important for human nutrition (Górnaś al., 2016) cited in the research of (Qian Ying et al., 2018). The pumpkin family (Cucurbitaceae) includes about 800 species in 120 variety.

The basic genius of that family is the pumpkin (Cucurbitaceae). This family includes several species: Cucurbita maxima, C. moschata, C. ficifolia, C. argyrosperma, C. turboniformis. The so-called common pumpkin (Cucurbita 
pepo L.) is mostly grown in our country. Cold pressed pumpkin oil has a dark green color. It is most often used to improve the taste of salads, vegetables and in medicine in the form of gel capsules. This oil contains unsaturated fatty acids, minerals and vitamins, tocopherols, phenolic compounds, phytosterols, etc. Pumpkin seeds and seed oil have many positive pharmacological and nutritional properties (Dimič Etelka et al., 2009). Nigella sativa, is a green annual plant that belongs to the family Ranunculaceae. Black seed oil has a brownishgreen color, oily texture and a characteristic odor. It contains more than 100 active highly balanced substances (saturated and unsaturated fatty acids, calcium copper, zinc, phosphorus, iron, $B$ vitamins such as: $B_{1^{\prime}} B_{2^{\prime}} B_{3^{\prime}}$ $B_{6^{\prime}}$ and $B_{9^{\prime}} 15$ amino acids amino of which 9 are essential amino acids). Black seed oil contains many other compounds that have antioxidant, antimicrobial, antifungal, anti-parasitic, antidiuretic and anti-spasmodic properties. The purpose of our research was to investigate the effect of different concentrations of cold pressed pumpkin oil and cold pressed black seed oil, on the chemical composition and oxidative changes (degree of acidity and peroxide value) of Bacon Folk sausages.

\section{Material}

Bacon Folk sausages produced in the meat industry in the R. Macedonia served as a material for examination. According to the Rulebook for demands regarding quality of minced meat, meat preparations and meat products (Official Gazette of Republic of Macedonia No. 63 from 29.04.2013), this sausage belongs to the group of semi-permanent coarse chopped boiled sausages. The production of the sausage was in compliance with all sanitary and veterinary regulations applicable in Macedonia. The sausages were produced according to the following recipe: $3 \mathrm{~kg}$ chicken MDM; chicken drumstig $12 \mathrm{~kg}$; pork triming $35 \mathrm{~kg}$; solid fat 40 kg; leek 3 kg; nitrite salt 1.7 kg; spice mix 0.400 kg; polyphosphate 0.500 kg; emulsifier $2.0 \mathrm{~kg}$; hard water - ice 5,0 kg.

Four groups of Bacon Folk sausages were prepared for the experiment: I group - without addition of cold pressed pumpkin oil (control group); Il group - with addition of $3 \mathrm{~g} / \mathrm{kg}$ cold pressed pumpkin oil; III group - with addition of $4 \mathrm{~g} / \mathrm{kg}$ cold pressed pumpkin oil, IV group with addition of $5 \mathrm{~g} / \mathrm{kg}$ cold pressed pumpkin oil.In the same order the other four groups was made in which cold pressed black seed oil was applied. Cold pressed pumpkin oil and black seed are bought from the trade network - in the market and are used in the production of groups of bacon sausage.
Cold pressed oils were applied during the mixing of the mixture. After preparation and mixing, the mix is stuffed in natural pork intestines with diameter 32-34 mm. After stuffing and pressing, the sausage were thermally processed, according to the following formula: 35 minutes drying at $62^{\circ} \mathrm{C}, 20$ minutes smoking at $62^{\circ} \mathrm{C}, 35$ minutes boiling at $78^{\circ} \mathrm{C}$. After thermal processing, the sausages were vacuumed with vacuum machine Vebomak. After vacuuming, the sausages were stored at refrigerator at temperature of $+4^{\circ} \mathrm{C}$.

\section{Methods}

The chemical composition was tested by using standard test methods commonly used in the chemical composition: Water by drying method at $105^{\circ} \mathrm{C}$; fats by the Gerber method; proteins was tested by the Kjeldahl method; mineral substances (ash) by the burning method. Three repetitions were made $(n=3)$. The degree of acidity was examined according to the method MKC EN 1410 (2007). The peroxide value was examined according to the method MKC ISO 27101 (2011).

Each parameter was determined after three repetitions, and the results are presented as mean value \pm Sd. The obtained results are mathematically and statistically processed in Microsoft Excel, 2003. 


\section{Determination of chemical composition \\ The results from the impact of cold-pressed \\ composition on Bacon Folk sausages are given in (Table 1).} pumpkin and black seed oils on the chemical

Table 1 Chemical composition of Bacon Folk sausage groups on the 1st and the 60th day of production $(n-3$, Mean \pm SD)

\begin{tabular}{|l|c|c|c|c|}
\hline \multicolumn{5}{|c|}{$\begin{array}{c}\text { Cold pressed pumpkin oil } \\
\text { 1 st day of production }\end{array}$} \\
\hline Parameters (\%) & Group I & Group II & Group III & Group IV \\
\hline Water & $54.61 \pm 0.12$ & $53.35 \pm 0.42$ & $52.24 . \pm 0.72$ & $52.83 \pm 0.20$ \\
\hline Fats & $26.50 \pm 0.08$ & $29.75 \pm 0.18$ & $30.25 \pm 0.48$ & $30.00 \pm 0.22$ \\
\hline Proteins & $11.86 \pm 0.12$ & $11.95 \pm 0.52$ & $11.65 \pm 0.42$ & $11.88 \pm 0.18$ \\
\hline Mineral matters (ash) & $4.46 \pm 0.52$ & $4.37 \pm 0.48$ & $4.24 \pm 0.20$ & $4.32 \pm 0.40$ \\
\hline \multicolumn{5}{|c|}{$\mathbf{6 0}^{\text {th }}$ day of production } \\
\hline Parameters (\%) & Group I & Group II & Group III & Group IV \\
\hline Water & $51.59 \pm 0.12$ & $50.57 \pm 0.28$ & $50.98 \pm 0.18$ & $53.58 \pm 0.48$ \\
\hline Fats & $26.50 \pm 0.10$ & $28.00 \pm 0.40$ & $29.50 \pm 0.70$ & $28.50 \pm 0.40$ \\
\hline Proteins & $11.52 \pm 0.20$ & $11.70 \pm 0.48$ & $12.01 \pm 0.40$ & $12.00 \pm 0.18$ \\
\hline Mineral matters (ash) & $4.46 \pm 0.52$ & $4.37 \pm 0.22$ & $4.44 \pm 0.78$ & $4.57 \pm 0.42$ \\
\hline \multicolumn{5}{|c|}{ Cold pressed black seed oil } \\
\hline Parameters (\%) & Group I & Group II & Group III & Group IV \\
\hline Water & $53.58 \pm 0.18$ & $51.59 \pm 0.14$ & $51.67 \pm 0.20$ & $51.72 \pm 0.22$ \\
\hline Fats & $26.25 \pm 0.12$ & $28.00 \pm 0.08$ & $28.00 \pm 0.24$ & $28.00 \pm 0.12$ \\
\hline Proteins & $12.19 \pm 0.28$ & $12.07 \pm 0.18$ & $12.00 \pm 0.22$ & $12.21 \pm 0.28$ \\
\hline Mineral matters (ash) & $3.62 \pm 0.18$ & $3.68 \pm 0.12$ & $3.80 \pm 0.22$ & $3.94 \pm 0.24$ \\
\hline \multicolumn{5}{|c|}{$\mathbf{6 0}$ th day of production } \\
\hline Parameters (\%) & Group I & Group II & Group III & Group IV \\
\hline Water & $54.61 \pm 0.22$ & $52.63 \pm 0.24$ & $51.73 \pm 0.18$ & $52.24 \pm 0.10$ \\
\hline Fats & $25,75 \pm 0.14$ & $28.00 \pm 0.12$ & $27.00 \pm 0.20$ & $28.00 \pm 0.18$ \\
\hline Proteins & $12.46 \pm 0.10$ & $12.66 \pm 0.18$ & $12.92 \pm 0.22$ & $12.21 \pm 0.10$ \\
\hline Mineral matters (ash) & $3.80 \pm 0.24$ & $3.98 \pm 0.18$ & $4.44 \pm 0.20$ & $3.82 \pm 0.12$ \\
\hline
\end{tabular}

On the first day of production at the groups of sausages produced with cold pressed pumpkin oil, there was a greater variation in the water and fat content between the first $(54.61 \pm 0.12)$ and fourth $(52.83 \pm 0.20)$, the second (53.35 \pm 0.42$)$ and fourth group $\quad(52.83 \pm 0.20)$, (in terms of the water content) and the first $(26.50 \pm 0.08)$ and fourth $(30.00 \pm 0.22)$, the second $(29.75 \pm 0.18)$ and the fourth group (30.00 \pm 0.22$)$, (in terms of fat content). While on the 60th day of production, there are differences in water and fat content between the first $(51.59 \pm 0.12)$ and fourth (53.58 \pm 0.48$)$, second ( $50.57 \pm 0.28$ ) and fourth group (53.58 \pm 0.48 ), and the third $(50.98 \pm 0.18)$ and fourth group $(53.58 \pm 0.48)$, (in terms of water content), and between the first (26.50 \pm 0.10$)$ and third (29.50 \pm 0.70$)$, first (26.50 $\pm 0.10)$ and fourth $(28.00 \pm 0.18)$, (in terms of fat content).

On the first day of production of the sausage groups produced with cold pressed black seed oil, a greater variation in water and fat content was observed between the first $(53.58 \pm 0.18)$ and second (51.59 \pm 0.14$)$, first $(53.58 \pm 0.18)$ and third group $(51.67 \pm 0.20)$ and the first $(53.58 \pm 0.18)$ and fourth $(51.72 \pm 0.22)$, (in terms of water content) and the first $(26.25 \pm 0.12)$ and the second ( $28.00 \pm 0.08)$, first $(26.25 \pm 0.12)$ and third group (28.00 \pm 0.24$)$ and first $(26.25 \pm 0.12)$ and fourth group $(28.00 \pm 0.12)$, (in terms of fat content).

While on the 60th day of production, there are differences in the water and fat content of the first $(54.61 \pm 0.22)$ and the second $(52.63 \pm$ $0.24)$, the first ( $54.61 \pm 0.22)$ and the third (51.73 $\pm 0.18)$ and the first $(54.61 \pm 0.22)$ and the fourth 
group ( $52.24 \pm 0.10)$, (in terms of water content). In terms of fat content there are differences between the first $(25.75 \pm 0.14)$ and the second $(28.00 \pm 0.12)$, the first $(25.75 \pm 0.14)$ and the third group (27.00 \pm 0.20$)$ and the first $(25.75$ $\pm 0.14)$ and the fourth group (28.00 \pm 0.18$)$.

This finding is due to the higher fat content and hard water (ice) added during the product cuttering, or as a result of the packaging of insufficiently drained sausages. In terms of protein content there are no statistically significant differences between any of the examined groups of sausages.

Leng Gao et al. (2013) investigated the effects of replacing pork with pre-emulsified sunflower oil (using isolated soy protein) in the production of frankfurter. oil has increased protein content, reduced fat content and improved oxidative stability.

The results of the examination of the oxidative changes (degree of acidity and peroxide value in the examined groups of Bacon Folk sausages are given in Figures 1,2,3 and 4.

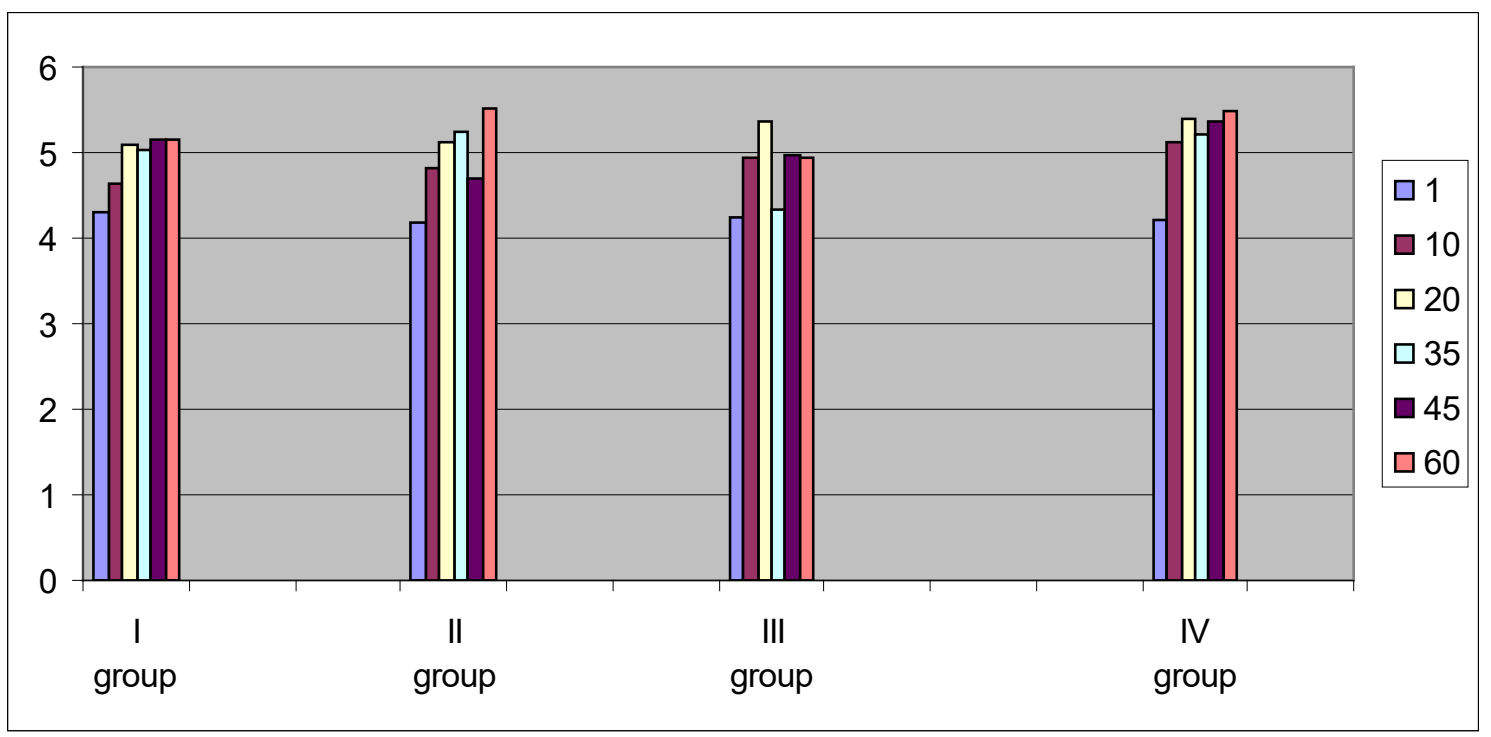

Figure 1. Degree of acidity in groups of sausages produced with cold pressed pumpkin oil (Fa)

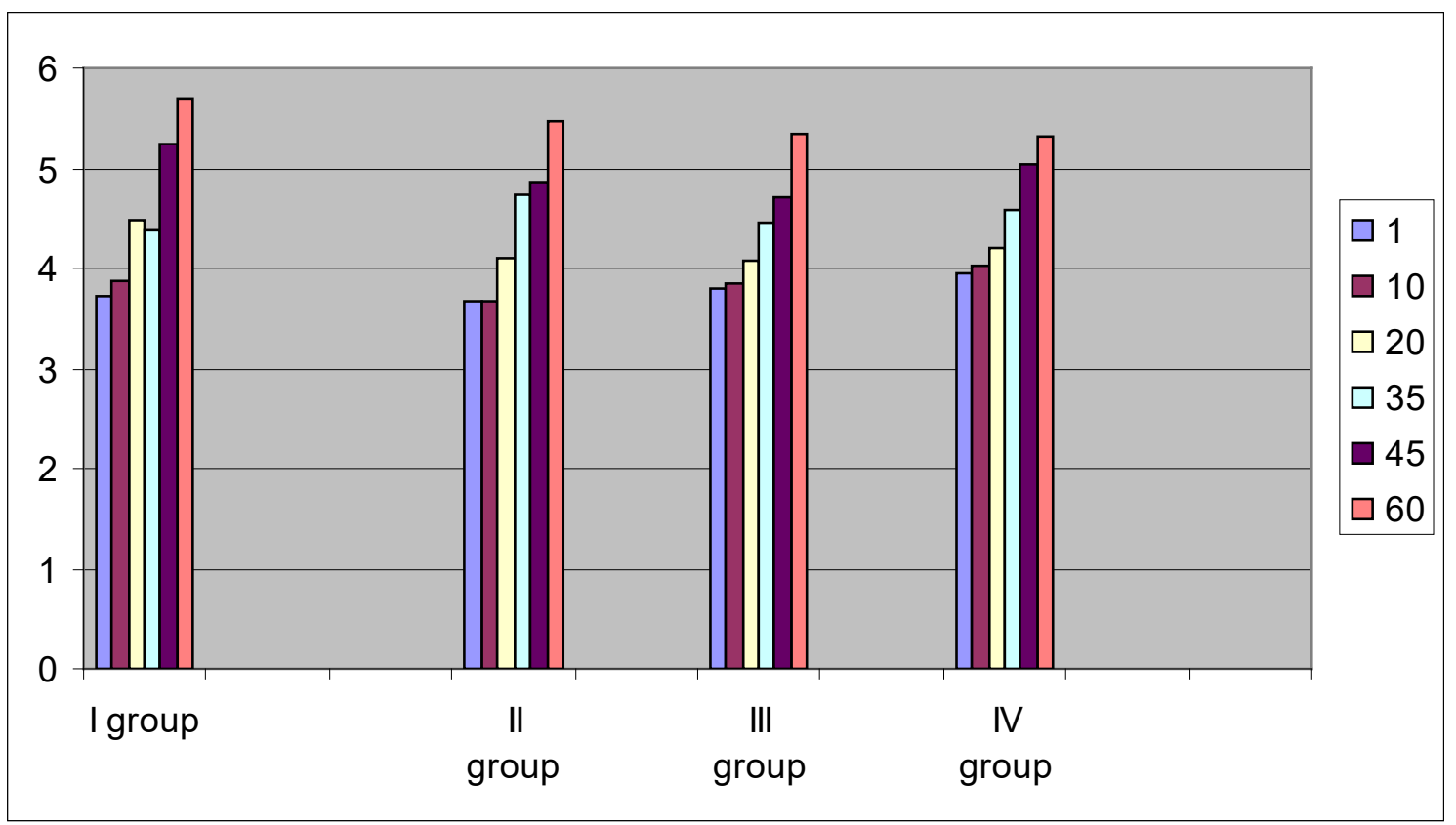

FIgure 2. Degree of acidity in groups of sausages produced with cold pressed black seed oil (Fa) 
Figure 1 and Figure 2 show that on the first day of production in the groups of sausages produced with cold pressed pumpkin oil, the acidity level is the lowest compared to the groups of sausages produced with cold pressed black seed oil. As the maturation increases in days, the degree of acidity increases in all groups and all types of cold pressed oils.

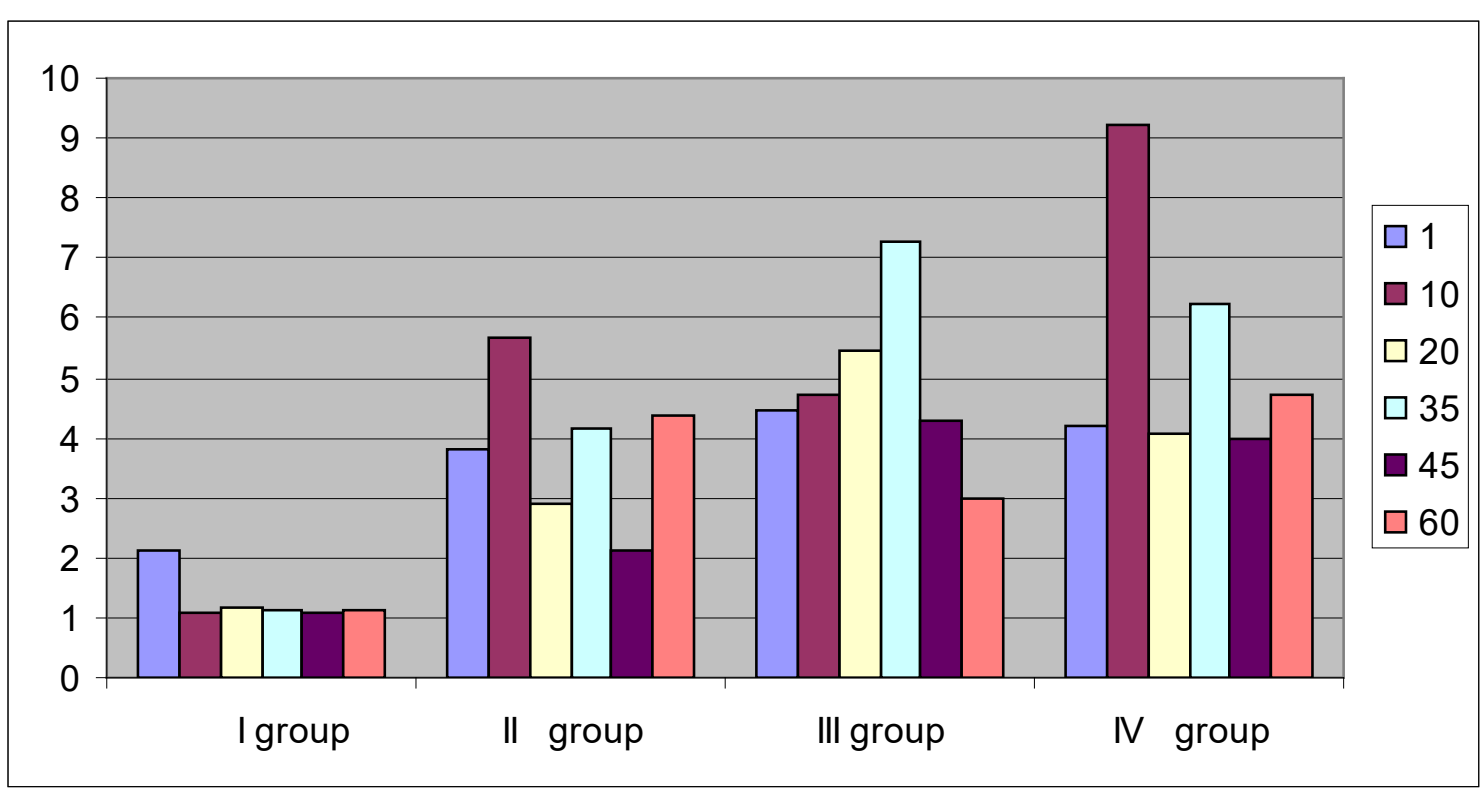

Figure 3. Peroxide value in groups of sausages produced with cold pressed pumpkin oil PN (mmol / kg)

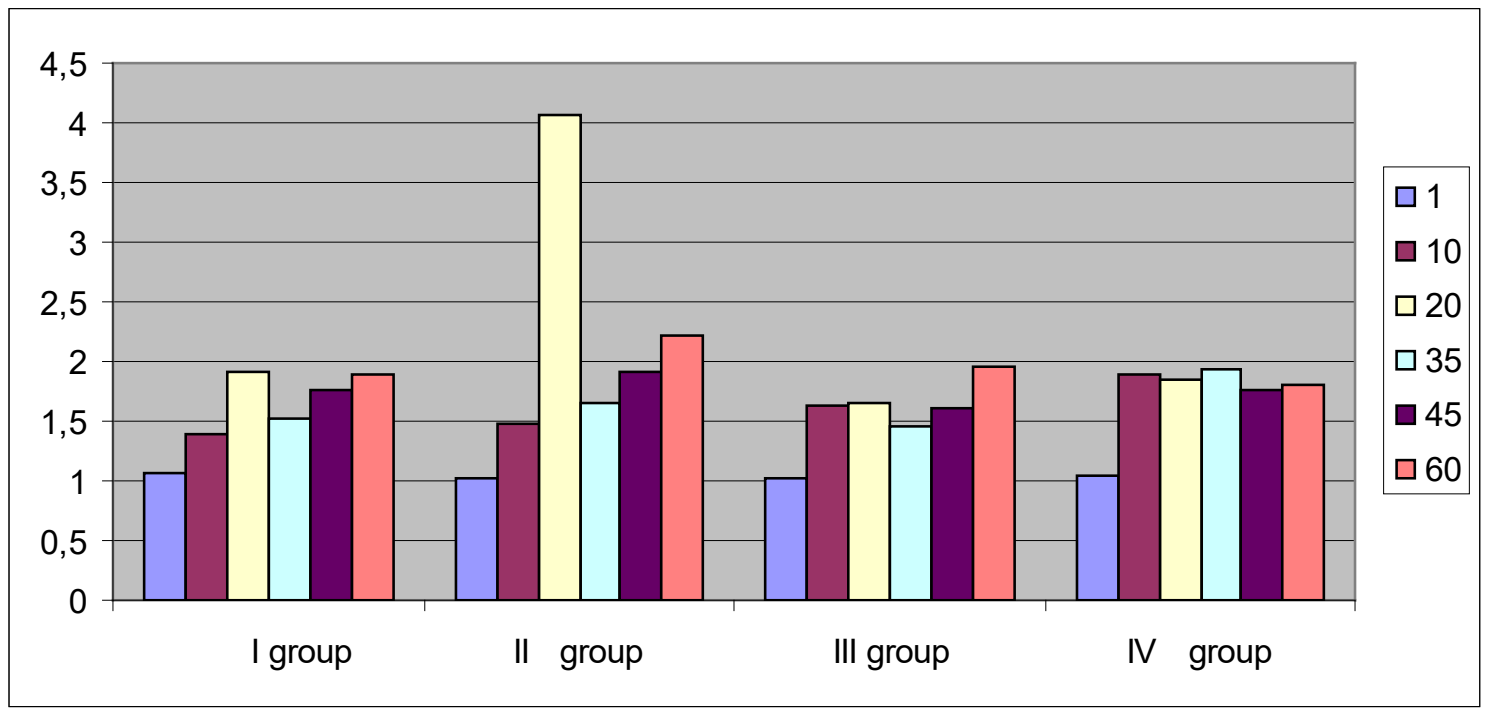

Figure 4. Peroxide value in groups of sausages produced with cold pressed black seed oil PN $(\mathrm{mmol} / \mathrm{kg})$

Figure 3 and Figure 4 show that on the first day of production in sausages produced with cold pressed black seed oil, the lowest peroxide number was found in all groups, compared to the groups of sausages produced with the addition of cold pressed pumpkin oil. The third group of sausages produced with cold pressed pumpkin oil has the highest peroxide number on the first day after production.

On the sixtieth day of production, the lowest peroxide number is in the first group of sausages, and the highest in the fourth group (Chart 3), in relation to the groups of sausages in (Chart 4). From the obtained research we can conclude that the biggest variations in terms of the peroxide number of all groups of sausages are in the groups of sausages in which cold pressed pumpkin oil is applied.

Because cold-pressed oils are used in our research, this means that the antioxidant activity 
of their bioactive components is not impaired, which was shown in the reduced values of the tested peroxide number in sausages.

Antova (2014) examined the antioxidative stability of ordinary and cold pressed pumpkin seed oil obtained from the Plovdiv region harvested in 2012. They found that cold pressed pumpkin seed oil has a higher

\section{CONCLUDING REMARKS}

From the performed examinations and the obtained results it could be concluded that all produced groups of sausages are in accordance with the Rulebook on quality, because their production technology is similar (group of steamed sausages). From the above mentioned, it could be concluded that the used concentrations of cold-pressed oils in the groups of sausages do not have impact on their chemical composition during storage at temperature of $4^{\circ} \mathrm{C}$. Degree of acidity and peroxide number of all tested sausage groups increased from the $1^{\text {st }}$ to the $60^{\text {th }}$ day of production. More obvious variations between

\section{REFERENCES}

Dimic, E., Vujasinovic, V., Romanic, R., \& Parenta G. (2009). Change of quality and biologicaly active components of pumpkin seed oil at $63 \pm 20^{\circ} \mathrm{C}$ during a 20 days period. Jornal Uljarstvo Vol 40 No 1 - 2. pp. 17-23.

Gornas, P., Rudzińska, M., Raczyk, M., Mišina, I. \& Seglin,a, D. ( 2016). Impact of cultivar on profile and concentration of lipophilic bioactive compounds in kernel oils recovered from sweet cherry (Prunus avium L.) by-products. Plant Foods Hum. Nutr., 71, 158-164.

Górnaś, P., Rudzińska, M., Raczyk, M., Mišina, I., Soliven, A., Lācis, G. \& Segliṇa, D., (2016). Impact of species and variety on concentrations of minor lipophilic bioactive compounds in oils recovered from plum kernels. J. Agric. Food Chem., 64, 898-905.

Górnaś, P., Rudzińska, M., Raczyk, M., Mišina, I., Soliven, A. \& Segliņa, D. (2016). Chemical composition of seed oils recovered from different pear (Pyrus communis L.) cultivars. J. Am. Oil Chem. Soc., 93, 267-274.

Obiedzińska, A. \& Waszkiewicz-Robak, B. (2012). Cold pressed oils as functional food.", Żywn. Nauka Technol. Jakość., 80, 27-44.

Petkova Zh. Antova, G., (2014). Oxidative stabillity of pumpkin seed oil and possibilities content of tocopherols (950 mg / kg) and has higher antioxidant stability (37.0 h) compared to ordinary pumpkin oil (tocopherol content $225 \mathrm{mg} / \mathrm{kg}$ and oxidative stability $21.4 \mathrm{~h}$ ). Due to its chemical composition and high oxidative stability, pumpkin seed oil can be used in food industry and medicine.

the sausage production series were observed in the peroxide number between the two groups on the last day of storage. The results obtained in this way are low and show stability during storage even when a functional component is added.

In our research, refined cold pressed pumpkin and black seed oils were used, which means that the antioxidant activity of their bioactive components is not disturbed, which was shown in the reduced values of the examined peroxide number in sausages.

of stabilizatio. Scientific Works of University of Food Technologies, Volume LX, pp. 259- 264.

Leng, G., Yang-Pin, H. \& Xiao-Chen, G.(2013). Influence of pre-emulsified sunflower oil used for pork backfat replacement in sika deer. Frankfurter Journal Food Sci. Technol. Res., 19 (5), 773 - 780, 2013.

Ying, Q., Wojciechowska, P., Siger, A., Kaczmarek, A., Okuda Rudzińska M. (2018). Phytochemical content, oxidative stability, and nutritional properties of unconventional coldpressed edible oils. Journal of Food and Nutrition Research. 6(7), 476-485.

Правилник за барањата во однос на квалитетот на меленото месо, пподготовки од месо и производи од месо Службен весник на Р. Македонија, број 63 од 2013 година. 


\section{КВАЛИТАТИВНИ КАРАКТЕРИСТИКИ НА КОЛБАСИ ПРОИЗВЕДЕНИ СО ДОДАТОК НА МАСЛО ОД ТИКВА И ЦРНО СЕМЕ}

\section{Бобан Малинов ${ }^{1 *}$, Ацо Кузелов²}

'Студент на втор ииклус студии на Катедрата за прехрамбена технологија и преработка на анимални производи, Земјоделски факултет, Универзитет "Гоче Делчев" - Штип, 2000 Штип, Република Северна Македонија

2универзитет „Гоче Делчев" - Штип, Земјоделски фракултет, 2000 Штип, Република Северна Македонија *Контакт автор: bobanmalinov@yahoo.com

\section{Резиме}

Во трудот се дадени резултатите од испитувањето на хемискиот состав и оксидативните промени (киселинскиот степен и пероксидниот број) на две групи барени сланински колбаси произведени со додаток на ладно цедено масло од тиква и црно семе. Хемискиот состав на колбасите е испитуван на првиот и на шеесеттиот ден од производството. Киселинскиот степен и пероксидниот број се испитувани на: првиот, десеттиот, дваесеттиот, триесет и петтиот, четириесет и петтиот и шеесеттиот ден од производството. Во однос на содржината на протеини и минерални материи, не постојат статистички значајни разлики кај испитуваните групи на колбаси. Поголемо варирање во содржината на масти има кај групите III и IV произведени со додаток на ладно цедено масло од тиква и црно семе. Киселинскиот степен е понизок кај групите колбаси произведени со ладно цедено масло од црно семе. Со текот на зголемувањето на зреењето во денови се зголемува и киселинскиот степен и кај двете испитувани групи. На првиот ден од производството кај групите колбаси произведени со ладно цедено масло од црно семе е констатиран најмал пероксиден број, а на шеесеттиот ден од производството најмал пероксиден број има кај првата група колбаси произведени со додаток на ладно цедено масло од тиква.

Клучни зборови: хемиски состав, оксидативни промени, колбаси 